\title{
RYZYKO GWARANTA W ŚWIETLE PROJEKTU NOWELIZACJI USTAWY PRAWO ZAMÓWIEŃ PUBLICZNYCH
}

Kwestie związane z podziałem środków uzyskanych m.in. z danin publicznych różnią się w zależności od poszczególnych państw, z uwagi na odrębności cechujace poszczególne społeczności. W Polsce wspomniane zasoby rozdysponowane sa przez wyznaczone instytucje, które dokonują tego zgodnie właśnie z Prawem zamówień publicznych ${ }^{1}$. W powyższym procesie podziału swój udział maja gwaranci, którzy zabezpieczają wierzytelności zarówno podmiotów udzielających zamówień, jak i ich wykonawców. Ustawa ta na przestrzeni lat była ciagle nowelizowana, co przede wszystkim wywołane było obowiązkiem wdrożenia regulacji unijnych do prawa polskiego. Również i w tym przypadku chęć wdrożenia przepisów wspólnotowych jest głównym czynnikiem motywującym do wprowadzenia zmian, które dla wielu uczestników rynku będą budować nową rzeczywistość w kwestii współpracy z sektorem publicznym. Celem niniejszego artykułu jest więc przedstawienie i analiza zmian ryzyka gwaranta w świetle projektu nowelizacji ustawy Prawo zamówień publicznych, mającej wejść w życie 18 kwietnia 2016 r. ${ }^{2}$ Autor zdecydował się postawić następująca hipotezę: Ryzyko gwaranta ulegnie zmniejszeniu na skutek nowelizacji ustawy Prawo zamówień publicznych w brzmieniu zgodnym z projektem Rady Ministrów z 13 marca 2016 r. Do zbadania powyższego zagadnienia wykorzystana zostanie analiza aktów prawnych oraz tematycznych źródeł literaturowych.

\section{PROCES NOWELIZACJI USTAWY PRAWO ZAMÓWIEŃ PUBLICZNYCH}

Zgodnie z projektem nowelizacji ustawy Prawo zamówień publicznych data wejścia w życie tegoż aktu ustalona została na 14 dni od momentu jego ogłoszenia, co obrazuje tempo, w jakim wprowadzane sa tak istotne dla polskiej gospodarki regulacje. Oczywiście jest to tylko projekt ustawy, a co za tym idzie

\footnotetext{
${ }^{1}$ Ustawa z 29 stycznia 2004 r. - Prawo zamówień publicznych, Dz. U. 2015, poz. 2164 (dalej jako: p.z.p.).

${ }^{2}$ Projekt Rady Ministrów nowelizacji ustawy Prawo zamówień publicznych z 13 marca 2016 r. (wersja 29; dalej jako: n.p.z.p.).
} 
- w dniu pisania tego artykułu nie ma żadnej gwarancji, że w zaproponowanym kształcie wejdzie on na stałe do polskiego porządku prawnego. Spojrzenie odmienia jednak nieco kwestia bezpośredniej skuteczności dyrektyw unijnych po upływie terminu na ich implementację, które to moga stanowić bezpośrednią podstawę do dochodzenia praw jednostek przed sądem krajowym ${ }^{3}$. Wspomniany projekt ma bowiem służyć inkorporacji do prawa polskiego trzech dyrektyw:

- 2014/24/UE z 26 lutego 2014 r. w sprawie zamówień publicznych, uchylającej dyrektywę 2004/18/WE (Dz. Urz. UE L 94 z 28 marca 2014 r., s. 65),

- 2014/25/UE z 26 lutego 2014 r. w sprawie udzielania zamówień przez podmioty działajace $\mathrm{w}$ sektorach gospodarki wodnej, energetyki, transportu i usług pocztowych, uchylającej dyrektywę 2004/17/WE (Dz. Urz. UE L 94 z 28 marca 2014 r., s. 243),

- 2014/23/UE z 26 lutego 2014 r. w sprawie udzielania koncesji (Dz. Urz. UE L 94 z 28 marca 2014, s. 1).

$\mathrm{Z}$ uwagi na budowę dyrektyw unijnych, będących instrumentem harmonizującym, rozsądny prawodawca dąży do implementacji ich za pomoca środków przewidzianych przez własny, krajowy porządek prawny, konkretyzując bardzo ogólne i pozostawiające dużo swobody przepisy aktu wspólnotowego. To właśnie chęć uszczegółowienia norm prawa unijnego celem uniknięcia negatywnych konsekwencji oraz ograniczony czas na implementację pozwalają twierdzić, że projekt (pomimo częściowej niedoskonałości) zostanie przez obecny Sejm uchwalony i stanie się częścią powszechnie obowiąującego prawa.

Dodatkowo Rada Ministrów po wprowadzeniu nowelizacji zamierza doprowadzić do poprawy przejrzystości Prawa zamówień publicznych, co osiagnięte ma zostać poprzez uchwalenie aktu jednakiej rangi i o tej samej nazwie. Już dziś wiadomo więc, że daną dziedzinę prawa czekają poważniejsze zmiany, jednak nieznana jest dokładna data ich dokonania. Do obecnej ustawy bowiem zostało do tej pory uchwalonych około pięćdziesięciu aktów zmieniających, które burza pierwotny zamysł prawodawcy co do jej podziału i konstrukcji. Mając to na uwadze, trzeba uznać za słuszną koncepcję syntezy, jednak o ile idea wydaje się trafna, o tyle sama droga dochodzenia do niej nie prezentuje się już tak dobrze. Przede wszystkim chodzi o czas, w jakim podejmuje się pierwsze kroki zmierzające do uchwalenia ustawy, które w przypadku Polski miały swój początek 21 kwietnia 2015 r. Dla porównania można podać przykład Wielkiej Brytanii, gdzie omawiane regulacje dotyczące zamówień publicznych (będące implementacją dyrektyw unijnych) weszły w życie 26 lutego 2015 r. Oczywiście pomiędzy tzw. civil law a common law istnieją olbrzymie różnice na gruncie legislacyjnym, instytucjonalnym oraz sądowniczym, jednakże pomimo powyższego dalej należy utrzymywać, że działania organów polskich są mocno spóźnione.

${ }^{3}$ K. Głębocki, Bezpośrednia skuteczność dyrektyw wspólnotowych $w$ krajowym porzqdku prawnym, http://www.ce.uw.edu.pl/pliki/pw/3-1999_Glebocki.pdf [dostęp: 13.01.2016]. 


\section{GWARANCJE UBEZPIECZENIOWE W USTAWIE PRAWO ZAMÓWIEŃ PUBLICZNYCH}

Z Prawem zamówień publicznych silnie związany jest rynek ubezpieczeniowy, który dostarcza instrumenty służące zabezpieczeniu wierzytelności przysługujących stronom postępowania. Mowa jest o gwarancjach ubezpieczeniowych, których w akcie prawnym wyszczególnione są trzy rodzaje, tj. zapłaty wadium, zaliczki oraz należytego wykonania kontraktu przez jego wykonawcę. Oczywiście nie są to jedyne możliwe do wykorzystania instrumenty, jednak tylko one mogą być dostarczone przez zakłady ubezpieczeń podmiotom ubiegającym się o otrzymanie zamówienia publicznego. Ponadto z uwagi na ograniczone możliwości wyboru rodzaju zabezpieczenia po stronie wykonawcy, są to najczęściej udzielane gwarancje na rynku, obok gwarancji wystawianych biurom podróży. Przed omawianiem konsekwencji zmian prawnych należy zdaniem autora przedstawić pokrótce istotę i potrzebę wystawiania wskazanych gwarancji w procesie o udzielenie zamówienia publicznego.

Gwarancja zapłaty wadium jest gwarancja, z którą ubezpieczyciele wiążą najmniejsze wymogi dotyczące oceny ryzyka ze strony osoby wykonawcy. Wpływ mają na to stosunkowo niskie kwoty pieniężne, jakie zakłady zobowiązane są na mocy umowy pokryć, o czym stanowi wprost art. 45 ust. 4 p.z.p. Ustanawia on limit wysokości wadium, jakiego zamawiajacy może żądać od podmiotów uczestniczących w postępowaniu. Zgodnie ze wskazanym przepisem może on znajdować się na poziomie nie większym niż $3 \%$ wartości zamówienia, co zwykle nie stanowi zbytnio wygórowanej kwoty dla zakładów ubezpieczeń, ale może być uciążliwe dla potencjalnych wykonawców. Chcąc więc uchronić się przed koniecznością zamrażania swoich środków na wczesnym stadium postępowania, oferenci składają w zamian m.in. właśnie gwarancje ubezpieczeniowe, których koszt jest znacznie niższy, gdyż wynosi zwykle ok. 1\% wysokości wadium. Celem zaś wspomnianego wadium jest zabezpieczenie interesów zamawiającego, gdyby oferent okazał się nierzetelny, tj. w szczególności odmówił podpisania umowy z zamawiajacym na warunkach zaproponowanych w złożonej przez siebie ofercie ${ }^{4}$. Wówczas to na gwarancie będzie ciążył obowiąek zapłaty wspomnianej już kwoty, przy czym będzie on miał możliwość podjęcia próby windykacji wypłaconych środków od oferenta z przyjętych wcześniej zabezpieczeń ${ }^{5}$.

Drugim rodzajem zabezpieczenia, które związane jest ściśle z usługami ubezpieczeniowymi, jest gwarancja zapłaty zaliczki, o której mowa w art. 151a ust. 5 p.z.p. Na potrzeby niniejszego artykułu należy wyłącznie wspomnieć, że nie jest to instrument tożsamy z zadatkiem, o którym mowa w art. 394 k.c. ${ }^{6}$, choć w przypadku zamówień publicznych różnice pomiędzy obiema instytucja-

${ }^{4}$ J. Kukiełka, D. Poniewierka, Ubezpieczenia finansowe, Oficyna Wydawnicza Branta, Warszawa 2003, s. 141.

${ }_{5}^{5}$ Zob. szerzej M. Sieradzka, Instytucja wadium w postępowaniu o udzielenie zamówienia publicznego, C. H. Beck, Warszawa 2015, s. 5.

${ }^{6}$ Ustawa z 29 stycznia 1964 r. - Kodeks cywilny, Dz. U. 2014, Nr 0, poz. 121. 
mi często ulegają marginalizacji ${ }^{7}$. Przedmiotem tejże gwarancji jest zobowiązanie zakładu do zapłaty określonej kwoty, gdy wykonawca odmówił zwrotu wypłaconej mu przez zamawiającego zaliczki w sytuacji, gdy doszło do niewykonania umowy. Omawiana zaliczka została zaś wypłacona wykonawcy, z uwagi na potrzebę poniesienia większych kosztów we wczesnym stadium realizacji zamówienia, co może znacznie pogorszyć jego płynność finansowa i narazić przedsięwzięcie na niepowodzenie.

Nieco inaczej wygląda kwestia gwarancji należytego wykonania kontraktu, która jest już produktem dużo bardziej skomplikowanym i wiążącym się ze znacznie większym ryzykiem dla zakładu ubezpieczeń niż omówiony wcześniej instrument. W związku z powyższym praktyka rynkowa wymusza na potencjalnych wykonawcach zamówienia publicznego jednoczesne ubieganie się o obydwa rodzaje gwarancji, z uwagi na możliwość niesprostania wyższym wymogom związanym chociażby z aspektami niefinansowymi, jak jakość kadry menadżerskiej czy doświadczenie w realizacji podobnych zobowiązań. Zakład ubezpieczeń $\mathrm{w}$ toku oceny ryzyka będzie wymagał od zleceniodawcy wystawienia gwarancji szczegółowej dokumentacji mającej posłużyć do weryfikacji realności wykonania zamówienia, gdyż to właśnie w przypadku jego niewykonania lub nienależytego wykonania ubezpieczyciel będzie zobligowany do wypłaty ustalonej sumy gwarancyjnej ${ }^{8}$. Zabezpieczenie ustala się w wysokości od $2 \%$ do $10 \%$ ceny całkowitej podanej w ofercie albo maksymalnej wartości nominalnej zobowiązania zamawiającego wynikającego z umowy, o czym stanowi art. 150 ust. 2 p.z.p. Cena gwarancji zależy zaś od wielu czynników, tj. chociażby czasu trwania gwarancji, sumy gwarancyjnej oraz indywidualnej oceny ryzyka związanego $\mathrm{z}$ określonym podmiotem.

W przypadku wystawienia wykonawcy obydwu gwarancji, tj. zwrotu zaliczki oraz niewykonania lub nienależytego wykonania kontraktu, obydwie sumy gwarancyjne są co do zasady od siebie niezależne, a więc beneficjent może żądać od gwaranta wypłaty dwóch wymienionych kwot.

Oczywiście nie są to jedyne rodzaje gwarancji ubezpieczeniowych, które moga zabezpieczać wierzytelności związane z zamówieniami publicznymi (np. gwarancje usunięcia wad i usterek). Powyższy opis jest w istocie bardzo ogólny i ma na celu jedynie wprowadzić czytelnika do tematyki gwarancji ubezpieczeniowych. Dalsza część artykułu poświęcona zostanie konkretnym zmianom prawnym oraz ich wpływowi na poziom ryzyka gwaranta przy zabezpieczaniu wierzytelności związanych z zamówieniami publicznymi.

\footnotetext{
7 Szerzej zob. w: M. Tenenbaum-Kulig, Instytucja zadatku w polskim prawie cywilnym, Wolters Kluwer, Warszawa 2008, s. 345.

${ }^{8}$ Zob. szerzej. T. Kwieciński, J. Pokrzywniak, P. Jarus, Wstrzymanie realizacji gwarancji ubezpieczeniowej lub bankowej na podstawie postanowienia sqdowego, „Wiadomości Ubezpieczeniowe" 2015, nr 2, s. 67-82.
} 


\section{WYBRANE ZAŁOŻENIA PROJEKTU USTAWY PRAWO ZAMÓWIEŃ PUBLICZNYCH}

Jak już wcześniej wspomniano, przez nowelizację ustawy Polska ma zamiar wprowadzić do krajowego porządku prawnego trzy dyrektywy unijne normujące zagadnienia z obszaru zamówień publicznych. Nadchodzace zmiany można z pewnością nazwać rewolucyjnymi, ponieważ na bok odchodzi kilka kwestii, które od lat miały zastosowanie w rzeczonym procesie. Mowa tutaj zwłaszcza o pisemności postępowania o udzielenie zamówienia publicznego oraz o kryteriach wyboru najlepszej oferty. Nie wszystkie zmiany będą jednak miały wpływ na poziom ryzyka ponoszonego przez gwaranta, dlatego autor skupi się wyłącznie na tych relewantnych z punktu widzenia omawianego tematu. Zaliczyć do nich można z pewnością:

1) warunki wykluczenia podmiotu z postępowania o udzielenie zamówienia publicznego,

2) kryteria oceny ofert,

3) dopuszczalność zmiany umowy w procesie.

Największe kontrowersje w kontekście nowelizacji związane są z kwestia wykluczenia podmiotu z postępowania o udzielenie zamówienia publicznego, ponieważ do przepisów tę sferę normujących dodana została nowa instytucja, nieznana dotąd prawu polskiemu. Mowa jest o tzw. samooczyszczeniu, uregulowanym w art. 24 ust. 8 n.p.z.p., które znosi skutek obligatoryjnego wykluczenia podmiotu w przypadku wystapienia określonych we wspomnianym przepisie okoliczności. Do tej pory pewną możliwość usprawiedliwienia poprzednich działań wykonawcy przewidywał art. 24 ust. 2 a p.z.p. w stosunku do oferenta, który w okresie 3 lat przed wszczęciem postępowania w sposób zawiniony poważnie naruszył obowiązki zawodowe. Warto przy tym dodać, że powyższy przepis wyraźnie wskazuje na obydwa typy nastawienia wolicjonalnego oferenta, tj. winę umyślną i nieumyślna, a więc wystarczające jest tylko udowodnienie przez zamawiajacego zawinienia po stronie kontrahenta na podstawie dowolnych dowodów. Oferent z kolei może obecnie usprawiedliwić swoje naruszenie obowiązków zawodowych, okazując stosowne dokumenty, które podlegają ocenie zamawiającego. Trybunał Sprawiedliwości Unii Europejskiej w sprawie Forposta i ABC Direct Contact ${ }^{9}$ dokonał szczegółowej analizy pojęcia „poważne wykroczenie zawodowe”. Trybunał stwierdził, że pojęcie to obejmuje wszelkie zawinione uchybienia, które wpływają na wiarygodność zawodowa danego wykonawcy, a nie tylko naruszenia wasko rozumianych norm deontologicznych obowiąujących w zawodzie wykonywanym przez wykonawcę, które stwierdzane są przez organ dyscyplinarny ustanowiony dla tego zawodu lub w prawomocnym orzeczeniu sądowym. Należy jednak pamiętać, że kwestia „powagi wykroczenia” wymaga co do zasady przeprowadzenia konkretnej i zindywidualizowanej oceny postawy danego wykonawcy ${ }^{10}$.

${ }^{9}$ Wyrok Trybunału Sprawiedliwości Unii Europejskiej z 13 grudnia 2012 r., C-465/11 - Forposta i ABC Direct Contact, Lex, nr 1230044.

${ }_{10}$ A. Bazan, J. E. Nowicki, Komentarz do art. 24 ustawy Prawo zamówień publicznych, Lex 2015. 
W projekcie ustawy Prawo zamówień publicznych instytucja „,samooczyszczenia" idzie dużo dalej, ponieważ umożliwi wykonawcy udowodnienie swojej „rzetelności”, co pozwoli mu na złożenie swojej oferty w postępowaniu, z którego to musiałby zostać wykluczony. W szczególności może on to uczynić poprzez (art. 24 ust. 8 n.p.z.p.):

1) naprawienie szkody wyrządzonej przestępstwem lub przestępstwem skarbowym,

2) zadośćuczynienie za doznaną krzywdę lub zobowiązanie się do naprawienia szkody lub zadośćuczynienia za doznaną krzywdę,

3) wyczerpujące wyjaśnienie stanu faktycznego czynu oraz współpracę z organami ścigania oraz podjęcie konkretnych środków technicznych, organizacyjnych i kadrowych, które sa odpowiednie dla zapobiegania dalszym przestępstwom lub przestępstwom skarbowym lub nieprawidłowemu postępowaniu.

Instytucja ta rozszerza więc omawiany wcześniej art. 24 ust. 2a, ponieważ umożliwia usprawiedliwienie wcześniejszego postępowania wykonawcy nie tylko $\mathrm{w}$ razie poważnego naruszenia obowiązku zawodowego, ale i w przypadku popełnienia przez niego przestępstwa. Owe typy przestępstw wymienione zostały w art. 24 ust. 1 n.p.z.p., jednak z uwagi na ich liczbę zbędne wydaje się ich wymienianie. Na podkreślenie zasługuje jednak fakt, że wśród nich znaleźć możemy np. przestępstwo przeciwko wiarygodności dokumentów czy przestępstwo korupcji. Wspomnianej instytucji nie będzie wolno stosować tylko wtedy, jeżeli w stosunku do wykonawcy są orzeknie zakaz ubiegania się o udzielenie zamówienia publicznego oraz jeśli nie upłynie jeszcze określony w wyroku okres obowiązywania wspomnianego zakazu ${ }^{11}$. Dodać należy, że strona uprawniona do decydowania o kwestii wystarczalności dowodów przedkładanych przez oferenta jest zamawiający, o czym stanowi art. 24 ust. 9 n.p.z.p.

Ustawa z 29 sierpnia 2014 r. o zmianie ustawy - Prawo zamówień publicznych ${ }^{12}$, obowiąująca od 19 października 2014 r. wprowadzono zasadnicze zmiany w zakresie kryteriów oceny ofert. Główną przyczyną nowelizacji było ograniczenie stosowania przez zamawiajaccych ceny jako jedynego warunku przy wyborze wykonawcy, co uczyniono poprzez zmianę art. 91 ust. $2 \mathrm{i}$ wprowadzenie art. 91 ust. 2 a p.z.p. Dodano do wymienionych w ust. 2 przykładowych kryteriów oceny ofert, kryteria odnoszące się do aspektów społecznych i innowacyjnych, a także rozszerzono opis kryteriów środowiskowych. Od wejścia $\mathrm{w}$ życie nowelizacji stosowanie ceny jako jedynego kryterium wyboru oferty jest możliwe w stosunku do tych zamówień, których przedmiot jest powszechnie dostępny oraz ma ustalone standardy jakościowe, natomiast w innych przypadkach zamawiający jest obowiązany zastosować obok ceny również inne warunki.

Sytuacja ulegnie jeszcze większej zmianie, gdy znowelizowane zostanie Prawo zamówień publicznych w brzmieniu zgodnym z projektem Rady Ministrów,

11 Art. 24 ust. 7 n.p.z.p. wskazuje ponadto na okres 5 lat od wydania prawomocnego orzeczenia skazującego wykonawcę za jedno z przestępstw wymienionych w ust. 1, po którego to upływie danego podmiotu wykluczyć z postępowania nie można, chyba że w wyroku przewidziano okres dłuższy.

12 Ustawa z 29 sierpnia 2014 r. o zmianie ustawy - Prawo zamówień publicznych, Dz. U. 2014, poz. 1232. 
który stanowi podstawę naszych rozważań. Sam kierunek ewolucji zostanie zachowany, jednak będzie to kolejny etap, w którym położony zostanie jeszcze większy nacisk na wybór oferty najkorzystniejszej ekonomicznie. Niewiele ponadroczne doświadczenia funkcjonowania nowelizacji uczą bowiem, że kryteria pozacenowe (pozakosztowe) moga być dość łatwo obchodzone. Czyni się to zazwyczaj przez przyznawanie bardzo niskich wag wspomnianym kryteriom, co $\mathrm{w}$ rezultacie je marginalizuje i sprawia, że to cena w dalszym ciagu odgrywa najistotniejszą rolę przy wyborze oferty. Swoistym remedium na dane praktyki będzie wprowadzenie limitu znaczenia kryterium ceny, który ukształtowany został na poziomie $60 \%$ wszystkich czynników ${ }^{13}$. Niestety powyższa sytuacja wywołana jest często niezrozumieniem ze strony zamawiających istoty kryteriów pozacenowych, przez co dążą oni do uniknięcia ich stosowania albo popełniaja błędy w ich doborze do poszczególnych kontraktów. Warto dodać, że obecnie najczęściej stosowanymi kryteriami są (oprócz ceny) termin realizacji zamówienia oraz okres gwarancji, jednak w wielu przypadkach nie mają one większego znaczenia dla meritum sprawy, jak np. termin dostawy przy zakupie urządzeń elektronicznych ${ }^{14}$. To właśnie dlatego korzyści z wprowadzenia omawianych zmian będą zauważalne dopiero po przygotowaniu zamawiających do należytego wykorzystywania przewidzianych w nowej ustawie instrumentów.

Kolejną istotną zmianą sa dodatkowe warunki, w których dopuszczalna jest zmiana postanowień umowy w stosunku do treści oferty, na podstawie której dokonano wyboru wykonawcy. Generalna zasadą w świetle zarówno obecnie obowiązującego Prawa zamówień publicznych, jak i nowelizacji jest zakaz dokonywania zmian istotnych, jednak obydwa wymienione akty zawierają różne katalogi okoliczności, dla jakich prawodawca przewiduje od niej odstępstwa. O powyższym stanowi art. 144 p.z.p. i w porównaniu z przepisami zawartymi w nowelizacji jest on dość lakoniczny, ponieważ wskazuje tylko na zakaz dokonywania zmian istotnych, chyba że zamawiający przewidział możliwość dokonania takiej zmiany w ogłoszeniu o zamówieniu lub w specyfikacji istotnych warunków zamówienia (SIWZ) oraz określił warunki takiej zmiany. Europejski Trybunał Sprawiedliwości w wyroku z 19 czerwca 2008 r. w sprawie Presse-text Nachrichtenagentur wskazał, co należy rozumieć przez pojęcie istotnej zmiany. Zatem ,zmiana zamówienia publicznego w czasie jego trwania może być uznana za istotna, jeżeli wprowadza ona warunki, które gdyby zostały ujęte $\mathrm{w}$ ramach pierwotnej procedury udzielania zamówienia, umożliwiłyby dopuszczenie innych oferentów niż ci, którzy zostali pierwotnie dopuszczeni lub umożliwiłyby dopuszczenie innej oferty niż ta, która została pierwotnie dopuszczona"15. Dopuszczalne będą więc zmiany nieistotne rozumiane w ten sposób, że wiedza o ich wprowadzeniu do umowy na etapie postępowania o udzielenie zamówienia publicznego nie wpłynęłaby na liczbę podmiotów ubiegających się o to zamówienie czy też na wynik postępowania ${ }^{16}$.

${ }^{13} \mathrm{~W}$ Niemczech limit ustalony został na poziomie $50 \%$.

${ }_{14}$ Szerzej o kryteriach pozacenowych zob. A. Szyszkowski, Pozacenowe kryteria oceny ofert w zamówieniach publicznych, C. H. Beck, Warszawa 2015, s. 54.

${ }^{15}$ Wyrok ETS z 19 czerwca 2008 r., C-454/06 - Presse-text Nachrichtenagentur, Legalis, nr 99361.

16 A. Bazan, J. E. Nowicki, Komentarz do art. 144 ustawy Prawo zamówień publicznych, Lex, nr 2015. 
Projekt nowelizacji ustawy prawo zamówień publicznych bardziej szczegółowo ujmuje okoliczności, w których dopuszczalna jest zmiana postanowień umowy w stosunku do treści oferty. Trzeba mieć na uwadze, że podobnie jak w obecnej ustawie dokonywanie wspomnianych zmian jest co do zasady niedozwolone, chyba że zachodzi co najmniej jedna z przesłanek wskazanych w rzeczonym akcie. Omawiane przepisy nowelizacji przede wszystkim konkretyzują dotychczasowe orzecznictwo Europejskiego Trybunału Sprawiedliwości, tj. chociażby uwzględniają wyroki w sprawach C-454/06 (Pressetext Nachrichtenagentur) czy C-496/99 (Succhi di Frutta) ${ }^{17}$. Bezcelowe wydaje się wskazywanie wszystkich przypadków dopuszczalności zmiany umowy, jednak przede wszystkim powiedzieć należy o art. 144 ust. 1 pkt 5 n.p.z.p., który odwołuje się do poprzedniej konstrukcji zmiany istotnej, scharakteryzowanej przez normodawce w ust. 1e wspomnianego artykułu. Jest to novum w stosunku do obecnej regulacji, gdzie zakres tego pojęcia wyznacza orzecznictwo krajowe i międzynarodowe, jak chociażby w wyroku Sąu Okręgowego w Szczecinie z 7 marca 2014 r..$^{18}$ czy w wyroku Trybunału Sprawiedliwości Unii Europejskiej w sprawie Wall $A G$ v. Frankfurt nad Menem ${ }^{19}$ ). Artykuł 144 ust. 1 pkt 3 przewiduje natomiast możliwość dokonania zmiany w przypadku zaistnienia okoliczności, której zamawiajacy, działając $\mathrm{z}$ należyta starannościa, nie był $\mathrm{w}$ stanie przewidzieć. Taka modyfikacja nie może jednak dotyczyć ogólnego charakteru umowy oraz jej wartość nie może przekroczyć 50\% pierwotnej wartości umowy w sprawie zamówienia publicznego. Po spełnieniu warunków określonych w ustawie można również mówić o zmianie dokonanej w celu zamówienia dodatkowych dostaw, usług, o dokonaniu zmiany przewidzianej uprzednio w umowie, czy wreszcie dokonaniu zmiany w celu dopuszczenia innego wykonawcy. Regulacja prawna jest zatem dużo obszerniejsza niż w poprzednim akcie, porządkuje dotychczasowe dokonania judykatury i odpowiada na wiele pytań stawianych dotychczas przez podmioty związane z postępowaniem o udzielenie zamówienia publicznego. Ostateczna ocena dokonana zostanie jednak w dalszej części artykułu.

\section{WPLYW ZALOŻEŃ PROJEKTU NOWELIZACJI NA RYZYKO PONOSZONE PRZEZ GWARANTA W POSTĘPOWANIU O UDZIELENIE ZAMÓWIENIA PUBLICZNEGO}

W poprzedniej części artykułu omówione zostały najważniejsze założenia projektu nowelizacji Prawa zamówień publicznych, dotykające pośrednio tematyki gwarancji ubezpieczeniowych oraz ryzyka związanego z ich oferowaniem. Dalsza część poświęcona będzie przewidywanym skutkom powyższych regulacji rozpatrywanym z perspektywy gwaranta oraz jego roli w samym pro-

17 Szerzej zob. J. Olszawska-Stompel, Prawo zamówień publicznych. Wybór najkorzystniejszej oferty $i$ zawieranie umów, rozdz. XIII: Zakres zmian $w$ umowach o zamówienie publiczne, Lex, 2013.

18 Wyrok SO w Szczecinie z 7 marca 2014 r., VIII GC 503/13.

19 Wyrok TSUE z 13 kwietnia 2010 r., C-91/08 - Wall AG v. Frankfurt nad Menem. 
cesie gwarantowania. Omówione rozwiązania wraz z planowanym wejściem w życie będą wpływały na poziom ryzyka ponoszonego przez zakłady ubezpieczeń, które z pewnością nie wycofają się z tej wprawdzie niebezpiecznej, ale i dochodowej działalności. Nowelizacja przepisów dotyczących zamówień publicznych zawsze wiąże się z silną reakcją społeczną z uwagi na wartość tego typu kontraktów oraz szeroki krąg podmiotów zainteresowanych wykonawstwem. To właśnie dlatego szczególnie istotna jest ich analiza w fazie projektowej lub na wczesnym etapie obowiązywania, która pozwala nie tylko na aprobatę rozwiązań słusznych, ale i w porę skłania do przemyśleń dotyczących mniej trafnych konstrukcji.

Przede wszystkim trzeba podkreślić, że gwaranci nie mają obowiązku zabezpieczania wierzytelności występujących w postępowaniu o udzielenie zamówienia publicznego. Gwarancja ubezpieczeniowa jest tylko jednym ze sposobów dokonania wspomnianego zabezpieczenia, a omawiane zmiany nie będa stanowiły kluczowych czynników decydujacych o podjęciu bądź też zaniechaniu omawianej działalności. Mogą one jedynie wpłynać na wzrost lub też spadek poziomu ryzyka, z jakim związana jest działalność gwarantowania, ale nie będą osia priorytetowa przy strategicznych decyzjach zakładu ubezpieczeń. Całkowita marginalizacja postanowień nowelizacji nie byłaby jednak wskazana, ponieważ większość zmian odciśnie swe piętno na procesie underwritingu, który w gwarancjach odgrywa znacznie większą rolę niż w pozostałych produktach ubezpieczeniowych ${ }^{20}$.

$\mathrm{W}$ toku analizy postanowień nowelizacji widać, że prawodawca europejski stara się dążyć do racjonalizacji postępowań o udzielenie zamówień publicznych w państwach członkowskich celem zwiększenia efektywności wydatkowanych środków budżetowych. Głównym założeniem zmian jest zwiększenie konkurencyjności, która w efekcie ma doprowadzić do poprawy jakości oferowanych przez wykonawców usług. Wydaje się, że właśnie te cele przyświecały modyfikacji okoliczności, w jakich podmioty moga zostać wykluczone z postępowania o udzielenie zamówienia publicznego. Mowa tutaj zwłaszcza o tzw. instytucji „samooczyszczenia”, która z pewnością wiazać się będzie z korzyścią w postaci większej możliwości zbycia produktu, jakim sa głównie gwarancje ubezpieczeniowe. Niestety powyższa regulacja w przekonaniu autora będzie się wiązała również z dwoma zagrożeniami dla gwaranta w postaci:

1) nacisku ze strony rynku na wystawianie gwarancji podmiotom, które skorzystały z powyższej instytucji,

2) ryzyka ponownego popełnienia przestępstwa przez wykonawcę w przyszłości (recydywa).

Po pierwsze, pomimo braku obowiązku zawarcia gwarancji może występować nacisk ze strony wykonawców korzystajaccych z instytucji „,samooczyszczenia" do wystawienia tego rodzaju zabezpieczenia. Pewna presja na zawarcie umowy przez zakład ubezpieczeń jest bowiem charakterystyczna w tej dzia-

${ }^{20}$ Szerzej na ten temat pisze J. Lisowski, Specyfika wydawania gwarancji ubezpieczeniowych, w: W. Ronka-Chmielowiec, K. Jajuga (red.), Inwestycje finansowe $i$ ubezpieczenia - tendencje światowe a rynek polski, t. 1, Prace Naukowe nr 1037, Wydawnictwo Akademii Ekonomicznej we Wrocławiu, Wrocław 2004, s. 386-393. 
łalności z uwagi na nierzadkie trudności z uzyskaniem niektórych rodzajów gwarancji, tj. chociażby należytego wykonania kontraktu. Podmioty silniejsze ekonomicznie, które mają zawarte z zakładem inne umowy ubezpieczenia, często stawiają ultimatum instytucji finansowej, szachując jej pozycję. Skalę problemu potęguje fakt, że do tej pory gwaranci mogli być pewni, iż w przypadku popełnienia przestępstw określonych w ustawie wykonawca będzie wykluczony z postępowania o udzielenie zamówienia publicznego, a przynajmniej zostanie on sprawdzony pod tym katem przy zawarciu umowy z zamawiajacym. W obecnym kształcie projektu zakłady ubezpieczeń musza zastosować dodatkowe środki ostrożności z uwagi na możliwość dopuszczenia tego rodzaju podmiotów do udziału we wspomnianym postępowaniu. Dodać należy, że o wystarczalności dowodów przedłożonych przez potencjalnego wykonawcę decyduje zamawiajacy, a nie gwarant, który z reguły posiada wieloletnie doświadczenie $\mathrm{w}$ zakresie oceny ryzyka związanego z postępowaniami o udzielenie zamówienia publicznego. Wszystko to sprawia, że osoba trzecia, czyli zamawiający, będzie pośrednio generowała zwiększone ryzyko dla gwaranta, który czasem może być przymuszony do zawarcia umowy gwarancji, licząc na lojalność wykonawcy w stosunku do innych produktów ubezpieczeniowych.

Po drugie, istnieje uzasadniona obawa, że osoba, która popełniła przestępstwo, w przeszłości może chętniej do niego powrócić w reakcji na słabsze sankcje ze strony systemu prawnego. W Polsce rokrocznie powiększa się liczba recydywistów, co oznacza, że systemy karania państwa nie przynosza pożądanego skutku. Oczywiście dane te odnoszą się do wszystkich rodzajów czynów zabronionych, jednak kluczowy jest czynnik, jaki popycha wspomniane osoby do takich dokonań, a jest nim - zdaniem ekspertów - miękki system karania w postaci warunkowego zawieszenia kary. Ponadto według danych z Ministerstwa Sprawiedliwości w 2014 r. odnotowano w Polsce wzrost korupcji i przestępstw przeciwko wiarygodności dokumentów, a więc takich czynów zabronionych, które sa relewantne z punktu widzenia omawianych zmian $^{21}$. Jeśli więc osobę, która już raz popełniła określone przestępstwo, dopuści się do postępowania o udzielenie zamówienia publicznego, to może istnieć większe ryzyko, że będzie ona pod tym względem skuteczniejsza w przyszłości. Należy zaznaczyć więc, że w połączeniu z ogólnym wzrostem ilości przestępstw gospodarczych w naszym kraju, instytucja określona w art. 24 ust. 8 n.p.z.p. w skrajnych przypadkach będzie generowała zagrożenie dla gwarantów udzielających zabezpieczeń wierzytelności na podstawie Prawa zamówień publicznych.

Z kolei zmianami, które z pewnością wpłyną na zmniejszenie ryzyka gwaranta, będą dalsze kroki w kierunku faworyzowania kryteriów pozacenowych przy wyborze najkorzystniejszej oferty. Jak już wspomniano, do tej pory system ten nieco zawodził ze względu na sposoby doboru wag preferujących cenę. W braku szczegółowych postanowień ustawy zamawiający marginalizowali kryteria pozacenowe, tak aby to kwota, jaką muszą zapłacić za usługę, była najistotniejsza w świetle specyfikacji istotnych warunków zamówienia.

${ }^{21}$ Ministerstwo Spraw Wewnętrznych, Raport o stanie bezpieczeństwa $w$ Polsce na rok 2014, http://bip.mswia.gov.pl/download/4/26163/RAPORT2014OSTATECZNY.pdf [dostęp: 9.02.2016]. 
Jeśli norma limitująca poziom wagi, jaką można przyznać cenie, wejdzie do porządku prawnego, znacząco ukróci możliwość dokonywania obecnych praktyk i zmusi podmioty do większych ruchów w kierunku kryteriów jakościowych. Niższe ryzyko dla gwaranta związane z tą instytucją zasadza się na twierdzeniu, że konkurencja pozacenowa wpływa korzystnie na stabilność finansową wykonawców, którzy nie muszą wyłącznie dążyć do obniżki kosztów, ale również do poprawy jakości i innowacyjności mogącej być elementem przetargowym w postępowaniu. Podobną sytuację dostrzec można na rynku ubezpieczeń komunikacyjnych, który przez ostatnie lata został mocno osłabiony przez tzw. wojnę cenowa, co w efekcie zaowocowało staraniami w kierunku tworzenia przewag jakościowych ${ }^{22}$. Szersze wprowadzenie kryteriów pozacenowych powinno również spowodować zmniejszenie się ilości ofert, których realizacja jest nieopłacalna. Stworzy to możliwość poświęcenia większej uwagi rozpatrywaniu dokumentów pozostałych podmiotów bioracych udział w postępowaniu, minimalizując tym samym ryzyko zarówno dla zamawiającego, jak i gwaranta. Powyższa kwestia została także zauważona przez Polską Izbę Ubezpieczeń, która w piśmie z 22 maja 2015 r. wyraziła swoją aprobatę co do wspomnianego systemu, ale i pewne zaniepokojenie, dostrzegajac potrzebę szerszych konsultacji społecznych dotyczących wyboru oferty najkorzystniejszej ekonomicznie ${ }^{23}$. Dyskusja powinna dotyczyć przede wszystkim metodyki oceny ofert i nadawania odpowiednich wag parametrom technicznym ofert, know-how i zapleczu technicznemu potencjalnych wykonawców. Tylko po uzyskaniu akceptacji interesariuszy zamówień publicznych będzie można liczyć na przestrzeganie norm prawnych i na osiagnięcie skutku założonego przez ustawodawcę.

Ocenie należy poddać również kwestie prawne dotyczące możliwości zmiany postanowień umowy w stosunku do treści oferty, na podstawie której dokonano wyboru wykonawcy. Za pozytywne należy uznać bardziej szczegółowe wymienienie w ustawie okoliczności, przy jakich zaistnieniu dozwolone sa modyfikacje, jak np. uprzednie zezwolenie na zmiany w umowie czy zamawianie dodatkowych dostaw, jeśli są niezbędne i nie przekraczają 50\% pierwotnej wartości umowy. Zaaprobować należy więc fakt dostrzeżenia problemu w kwestii niedookreślonych okoliczności zmiany umowy w obecnie obowiązującym Prawie zamówień publicznych, które były przedmiotem wielu spraw sądowych, dotyczących właśnie gwarancji ubezpieczeniowych ${ }^{24}$. W większości przypadków gwaranci zastrzegają bowiem, że wszelkie zmiany w umowie w sprawie zamówienia publicznego sa bezskuteczne w stosunku do ubezpieczyciela wystawiającego gwarancję, co często wywoływało spory w momencie zgłoszenia żądania wypłaty sumy gwarancyjnej. Bezdyskusyjnie należy rozróżnić skutki zmiany umowy w świetle Prawa zamówień publicznych od skut-

22 J. Lisowski, Wybrane aspekty konkurencji na rynku ubezpieczeniowym - ujęcie ekonomiczno-finansowe, w: M. Serwach (red.), Konkurencja i konkurencyjność na rynku ubezpieczeniowym, Wyd. Fundacja Instytut Zarządzania Ryzykiem Społecznym, Warszawa 2015, s. 51-80.

${ }^{23}$ Polska Izba Ubezpieczeń, Odpowiedź w trybie konsultacji publicznych z 22 maja 2015 r., https://legislacja.rcl.gov.pl/docs//2/12271652/12284974/12284977/dokument169243.pdf [dostęp: 10.02.2016].

${ }^{24}$ Przykładem będzie chociażby wyrok SO w Szczecinie z 7 marca 2014 r., VIII GC 503/13. 
ków, jakie taka zmiana wywoła na gruncie stosunku obligacyjnego łączącego gwaranta $\mathrm{z}$ beneficjentem. W przekonaniu autora zaproponowane $\mathrm{w}$ projekcie postanowienia wpłyną na uporządkowanie tej materii - zarówno gwaranci, zamawiający, jak i wykonawcy będą dokładniej znać zakres możliwych do dokonania zmian w umowie w czasie jej trwania. W efekcie umowy gwarancji będą mogły być lepiej przygotowane pod tym kątem, tak aby zminimalizować ryzyko niepewności związanej z procesem sądowym dla obydwu jej stron.

Na koniec warto poświęcić kilka słów kwestii należytego wykonania zamówienia, pojęciu, które wielokrotnie pojawia się w przepisach Prawa zamówień publicznych. Dane zagadnienie jest poruszane dopiero w tej części artykułu z uwagi na to, że chęć toczenia o nim dyskursu nie jest podyktowana zmiana ustawowa. Projekt Rady Ministrów nie dokonuje w tym aspekcie większych zmian, mianowicie nie definiuje pojęcia należytego wykonania umowy, utrwalając tym samym problematyczny dla stosujacych prawo stan obecny. Kontrowersje bowiem osadzają się wokół faktu, że niewykonanie bądź nienależyte wykonanie zobowiązania przez wykonawcę stanowi najczęściej dla gwaranta okoliczność powodująca obowiązek wypłaty sumy gwarancyjnej.

Brak zdefiniowania powyższego pojęcia ma jednak swoje uzasadnienie, które przejawia się w jego obszerności. Podkreśla się to również w literaturze, gdy mowa o ewentualnych roszczeniach, jakie moga zostać pokryte przez bardzo często wymagane zabezpieczenia właśnie należytego wykonania zamówienia $^{25}$. Do rzeczonych roszczeń zaliczyć możemy chociażby roszczenia o zapłatę: 1) odszkodowania z tytułu niewykonania lub nienależytego wykonania zobowiązania, 2) odszkodowania z tytułu zwłoki w wykonaniu umowy wzajemnej, 3) odszkodowania z tytułu niemożności wykonania świadczenia, za którą wykonawca ponosi odpowiedzialność, 4) odszkodowania z tytułu szkody wynikłej $\mathrm{z}$ niewykonania zobowiązania $\mathrm{z}$ umowy wzajemnej itd. Trudno jest więc syntetycznie zdefiniować dane pojęcie poprzez potencjalne prawa podmiotowe wymienione powyżej, z uwagi na ich niemałą liczbę. Również Krajowa Izba Odwoławcza (KIO) w wyroku z 18 kwietnia 2013 r. wypowiedziała się w kwestii interpretacji omawianego pojęcia stwierdzając, że „należyte wykonanie zobowiązania jest pojęciem ogólnym, niedookreślonym. O nienależytym spełnieniu świadczenia można mówić w aspekcie zachowania terminu, miejsca, sposobu lub jakości świadczenia itp. warunków wynikających z zawartej umowy" ${ }^{26}$. Czym innym jest jednak określenie dokumentów, jakie powinny stanowić podstawę do uznania należytego wykonania zamówienia, co w ostatnich latach stanowiło przedmiot rozstrzygnięć wielu procesów sądowych. Zdaniem autora prawodawca powinien w przyszłości dążyć do szczegółowego uregulowania wspomnianego zagadnienia, ponieważ zmniejszy to ryzyko gwaranta ponoszone w ramach udzielania gwarancji ubezpieczeniowych, stanowiących zabezpieczenie wykonania zobowiązania.

Rzeczona kwestia została również zauważona przez Polską Izbę Ubezpieczeń, która w piśmie z 2 lutego 2016 r. przekonuje do uzależnienia podjęcia decyzji o uznaniu należytego wykonania zamówienia od przedstawienia protoko-

25 P. Granecki, Prawo zamówień publicznych, C. H. Beck, Warszawa 2014, s. 940.

${ }^{26}$ Wyrok Krajowej Izby Odwoławczej z 18 kwietnia 2013 r., KIO 724/13, Legalis, nr 745407. 
łu odbioru robót albo innego dokumentu wykazującego zgodność wykonanych prac $^{27}$. Jeśli bowiem trudności przysparza sama definicja omawianego pojęcia, to powinno się wskazać chociaż zakres dokumentów, jakie mogą stanowić podstawę podjęcia wyżej wymienionej decyzji, podobnie jak w Rozporządzeniu Prezesa Rady Ministrów z 19 lutego 2013 r. ${ }^{28} \mathrm{Z}$ pewnością nie rozwiązałoby to całego problemu, jednak zdaniem autora byłby to krok w kierunku zwiększenia pewności prawnej dla podmiotów stosujących daną ustawę i zmniejszenia ryzyka związanego z działalnością gwarantów ${ }^{29}$.

\section{PODSUMOWANIE}

Implementacja dyrektyw unijnych do polskiego porządku prawnego jest krokiem naprzód w kierunku optymalizacji postępowania o udzielenie zamówienia publicznego. Bezsprzecznie projekt nowelizacji Prawa zamówień publicznych odpowiada na wiele pytań będących dotychczas przedmiotem analiz sądowych i ciągłych dyskusji w kręgu podmiotów stosujących obecne przepisy. Planowane zmiany będą także rezonować na sytuację gwaranta, który zdaniem autora będzie ponosił niższe ryzyko związane z wydawaniem gwarancji zabezpieczających wierzytelności w zamówieniach publicznych, co jest potwierdzeniem hipotezy przedstawionej we wstępie. Pewnych zagrożeń dla ubezpieczycieli można ewentualnie upatrywać w instytucji ,samooczyszczenia" i w ciagle to problematycznej kwestii należytego wykonania zamówienia. Możliwość ekskulpacji wykonawcy faktycznie może tworzyć pewne niebezpieczeństwo dla gwaranta, jednak zdarzenia takie będą raczej wyjątkiem niż powszechną regułą. Zagrożenia dla gwarantów są więc niewielkie, a negatywne konsekwencje wprowadzenia nowych regulacji będą występowały raczej sporadycznie, co nie powinno rzucać cienia na całość projektowanych postanowień.

mgr Sergiusz Lenhardt

Uniwersytet Ekonomiczny w Poznaniu

sergiusz.lenhardt@ue.poznan.pl

${ }^{27}$ Polska Izba Ubezpieczeń, Odpowiedź w trybie konsultacji publicznych z 2 lutego 2016 r., https://legislacja.rcl.gov.pl/docs//2/12281202/12333444/12333447/dokument209779.pdf [dostęp: 15.02.2016].

${ }^{28}$ Rozporządzenie Prezesa Rady Ministrów z 19 lutego 2013 r. w sprawie rodzajów dokumentów, jakich może żądać zamawiający od wykonawcy, oraz form, w jakich te dokumenty mogą być składane, Dz. U. 2013, poz. 231.

${ }^{29}$ Zob. szerzej H. Łopianowska, A. Packo, Zamówienia publiczne. Orzecznictwo sqdów okręgowych w latach 2010-2015 z komentarzem, Wolters Kluwer SA, Warszawa 2016, s. 334. 


\section{SURETY RISK IN THE CONTEXT OF THE DRAFT AMENDMENT TO THE PUBLIC PROCUREMENT LAW}

\section{Sum mary}

This article is devoted to a guarantor's risk related to the management of public procurements. Special attention is given to guarantee in this process and the risks associated with its sale. The aim of the article was to show the changes in terms of the guarantor's exposure to risk in connection with the amendment to the Public Procurement Law. The article consists of three main parts: the introductory, which presents the types of warranty occurring in the procedure for awarding a public contract, the detailed one on the specific provisions of the law analysed, and the third one which describes the changes in the risk of the guarantor in the new legal reality. 